\section{Estudo \\ Ecidebate}

em Testã⿻

Dlanejamento
Revista Estudo \& Debate, Lajeado, v. 27, n. 2, 2020. ISSN 1983-036X

DOI: http://dx.doi.org/10.22410/issn.1983-036X.v27i2a2020.2489

\title{
THE IMPACT OF INEFFICIENT AND INADEQUATE SANITATION DISEASES ON THE AVERAGE COST OF HOSPITAL ADMISSIONS IN BRAZILIAN MUNICIPALITIES
}

\author{
Rodrigo de Vasconcellos Viana Medeiros ${ }^{1}$, Thiago Corni Ferreira ${ }^{2}$
}

\begin{abstract}
The present work has as its objective to evaluate how the investment and sanitation indicators, as well as how the efficiency of those services affect the average cost of hospital stays due to parasitic-infectious diseases linked to poor sanitation in brazilian municipalities. To achieve the given objectives, the efficiency of sanitation services was measured using the data envelopment analysis technique and a multiple regression analysis was estimated using explanatory variables which captured the effect of an improvement in the quality and access to sanitation as well as an increase in investment on provided services. The results showed that $20 \%$ of municipalities have efficient services and that the investment in new water and sewer links to the installed sewage network, as well as an increase in the extension of water pipe links for each meter of the service network contribute to reduce the average cost of hospital stays due to diseases associated to inadequate sanitation. With respect to validity and adjustment of the model, its performance was deemed satisfactory having in mind the fact that it did not violate the necessary assumptions of the multiple regression model. With the results found it is possible to enlighten in an objective way that the main sanitation parameter that must be prioritized in a national policy which does not fail in its objectives is the increase in the access of piped water.
\end{abstract}

Key-word: Inadequate sanitation; Efficiency; Data Envelopment Analysis; Multiple Linear Regression

\section{IMPACTO DE LAS ENFERMIDADES VINCULADAS COM SANEAMIENTO INADECUADO E INAPROPRIADO SOBRE EL COSTO MEDIO DE LA HOSPITALIZACIÓN EM MUNICIPIOS BRASILEÑOS}

Resumen: Presente trabajo tiene como objetivo evaluar cómo los indicadores de inversión y saneamiento, así como la eficiencia de estos servicios, afectan el costo promedio de las hospitalizaciones por enfermedades infecciosas-parasitarias vinculadas a la falta de saneamiento inadecuado en los municipios brasileńos. Para lograr los objetivos propuestos, la eficiencia de los servicios de saneamiento se midió utilizando la técnica de Análisis de envoltura de datos y se estimó un modelo de regresión lineal múltiple con variables explicativas que capturaron el efecto de las mejoras en la calidad y el acceso al saneamiento, así como una mayor inversión en

1 Dsc. Student in Applied Economics at Universidade Federal de Viçosa (UFV).

2 Msc. Student in Applied Economics at Universidade Federal de Viçosa (UFV). 
servicios proporcionado. Los resultados mostraron que $20 \%$ de las ciudades tienen servicios eficientes y que la inversión en nuevas conexiones de agua y alcantarillado en la red instalada, así como el aumento en la extensión de las conexiones de agua para cada medidor de la red de servicio, contribuyen a reducir el costo promedio de hospitalizaciones con enfermedades vinculadas a saneamiento inadecuado. Con respecto a los aspectos de validez y ajuste, el desempeño del modelo fue satisfactorio en vista del hecho de que no violó los supuestos necesarios para la ejecución de la regresión lineal múltiple. Con los resultados del estudio, es posible aclarar objetivamente que el parámetro principal de saneamiento que debe priorizarse para que una política nacional de saneamiento no falle es la expansión del acceso al agua entubada.

Contraseñas: Saneamiento inadecuado; Eficiencia; Análisis de envoltura de datos; Regresión lineal múltiple.

\section{Introduction}

The access to water and sewage collection, as well as potable water supply has increased considerably across the world. However, in developing countries, this increase has been slower. In these countries, the water and sewage services are still significantly smaller in relation to developed countries and as a consequence, millions of people suffer from avoidable diseases every year.

According to the World Health Organization (WHO), in 2011, around 2.7 billion people in the world are still living under inadequate sanitation conditions and without some source of potable water. While $99 \%$ of the developed world population have adequate water and sewage system service available, in developing countries this number declines to $71 \%$ in urban areas and 39\% in rural areas (VAN MINH and HUNG, 2011).

According to Fewtrell et al. (2007), around 10\% of all diseases in the world are linked to this low coverage of adequate water and sewage collection supply. Diarreal infection and diseases caused by parasites (taeniasis, schistosomiasis, amoebiasis, among others), cause, every year, around 1.7 millions avoidable deaths, consuming medical resources (mainly in public hospitals) which could be allocated to more complex cases.

The sanitation sector is a big challenge to public management, because it presents characteristics of economies of scale and scope which justify the existence of a natural monopoly in its operationalization. Beyond that, the sector is also marked by low technological dynamism in distribution as well as in production which lead companies to have great variations in technology adoption (topography tools, water capture mechanisms, systems of residue management, among others) in its portfolio to provide services. (SEROA DA MOTTA and MOREIRA, 2006).

This vast array of technologies, together with the natural monopoly market condition, takes companies to manage its resource as such as to maximize its profits. The problem arises when this profit maximization does not lead to efficient provision of services, given that the monopoly position and regulatory condition of the sector which possesses incomplete concession contracts together with a lack of transparency around its subsidies and tariffs for the provided services (TUPPER and RESEND, 2004; SEROA DA MOTTA and MOREIRA, 2006).

According to Sabbioni (2008), those characteristics of the sanitation sector generate as a consequence, inefficiencies in delivering water and sewage services, showing that inadequate sanitation not only harms the health of individuals, it also raises public and 
private expenditures to the treatment of diseases that could be potentially avoided in case where an adequate structure for the water, sewage and waste treament existed.

According to Instituto Trata Brasil (ITB), in 2013, Brazil registered 340 thousand hospitalizations due to infections linked to the use of contaminated water and precarious sanitation and, according to the same entity, for each additional R $\$ 1.00$ invested in basic sanitation in that year, $\mathrm{R} \$ 4.00$ would have been saved in health expenses. This means, in absolute terms, a reduction of approximately 74 thousand hospitalizations, thus avoiding greater congestion in public health units.

Given this context, the present study seeks to analyze the impact of the efficiency and sanitation indicators (water and sewage) to the costs of hospitalizations in the public health sector in Brazilian municipalities for the year of 2018. Knowing the impacts of absence (or inadequate access) of sanitation services, it will be possible to direct public and private resources in this sector more effectively to the indicators which have the biggest impact on cost reduction for hospitalizations.

\section{Theoretical Framework}

\subsection{The impact of sanitation on hospital admissions}

Questions about sanitation in Brazil began, in fact, to gain "weight" in the early 1970s, when the government created the Plano Nacional de Saneamento (PLANASA) whose main objective was to significantly expand the access to water supply and bring sewage services to the population. However, economic and political instability in the following decades hindered full adoption of PLANASA's objectives and up until the end of the 20th century, the progress of what would be adequate basic sanitation was mostly stagnant. In 2007, bill No. $11445 / 07$ was enacted, which was considered the regulatory framework for sanitation in Brazil, which lead to the creation of the Plano Nacional de Saneamento Básico (PLANSAB) with guidelines and goals that the sector should fulfill (ROCHA, ROSSONI and FARIA, 2018).

The concept of basic sanitation arises from the distinction over what is adequate and inadequate in water and sewage services. These definitions are important because they define, respectively, secure and non-secure access to such services. Thus, according to the Plano Nacional de Saneamento Básico (PLANSAB, 2007), to guarantee safe access to sewage, the following factors are considered: septic tank, sewage channeling, composting system and latrines with slab covers. The safe water sources considered are: artesian well, piped water from public systems and propietary safe natural water sources. When one or more of these items are not available to the population, the problem of inadequate basic sanitation arises.

Inadequate access or, in many cases, the lack of sanitation is a potential cause of negative impacts on the health of the population as a whole, causing, from an economic perspective, negative externalities and constituting a complex public health problem. According to Fonseca and Vasconcelos (2017), this problem is much more prominent in developing countries. It is in these countries that the largest number of cases occur, such as 
Trachoma, Schistosomiasis, Hepatitis A, Skin diseases, Teniasis, diarrheal infections, among others which are typical from environments with poor sanitation.

According to Siqueira et al. (2017), these diseases should not cause hospital admissions, given that they can be potentially preventable. In addition, the World Health Organization (WHO, 2011) warns that a deficit in these services can lead to malnutrition, especially those with lower income levels, notably the portion of the population that is most impacted since they end up living on the periphery of large cities where, historically, sanitation has always been precarious in developing countries.

For the Brazilian case, Siqueira et al. (2017) show that there have been improvements regarding mortality from this type of disease. However, the authors point out that morbidity (the potential of an agent to cause illness in human beings) has not been satisfactorily reduced. Corroborating with this statement, Araújo (2017) shows that between 2006 and 2016 there was an increase in hospitalization expenditures caused by diseases related to inadequate sanitation in large Brazilian metropolitan regions, evidencing an increase in morbidity, especially among children under 1 year old and elderly among 60 and 69 years. According to the author, there was an increase of approximately $10 \%$ in the number of hospitalizations, which caused an increase in the average amount spent for hospitalizations to $\mathrm{R} \$ 1,673.98$. This increase, in real terms, meant an increase of $35 \%$ in the average expenditure per hospitalization, at national level.

Confirming the results of Araújo (2017), Fonseca et al. (2017) also detected an increase in hospitalizations in Brazilian regions. According to the study, the North region had the highest rates of hospitalizations per thousand inhabitants for diseases related to sanitation, with the state of Rondônia having a negative impact. The authors confirm that this result was expected considering that the North region is one of the main locations with the absence of these types of services. However, some states in the southeastern region such as Minas Gerais and Espirito Santo experience high rates, when compared to the total resources invested in sanitation. According to the authors, these results may demonstrate a lack of effective public policies in this area.

In order to find the relevant variables which impacted hospitalizations due to inadequate sanitation diseases, Scriptore and Azzoni (2018) performed a spatial analysis of the distribution of sanitation services in Brazil, relating hospitalizations attributed to diseases related to inadequate access to sanitation services to health care indicators.. The authors have stressed that many sanitation indicators can positively impact the number of hospitalizations, however it is the lack of bathroom facilities at home and open sewage sanitation that are the indicators that could potentially increase the number of hospitalizations in the Brazilian territory.

Authors such as Uhr, Schemel and Uhr (2016) and Begum, Ahmed and Sen (2011) highlight that this increase in hospitalizations and, consequently, the increase in hospitalization expenditures, could be avoided with public intervention, such as investing in greater sanitation infrastructure. According to the authors, providing treated water, for example, has an immediate effect on improving public health, as it eliminates a potential vector of diseases, in this case contaminated water. 
In many cases, the design and construction of programs for the Brazilian case have gone through great difficulties given its continental dimensions. However, with greater political effort and better institutional conditions for the development of such programs, it is possible to develop successful mechanisms. Duflo et al. (2015) present, for the Indian case, the impact of an integrated program for the provision of services related to access to septic tanks and piped water for each household in a specific rural location in India. The results showed that hospitalizations for diarrheal diseases can be reduced up to $50 \%$.

\subsection{Efficiency studies on the brazilian sanitation sector}

The application of the concept of efficiency is highlighted by works by M. J. Farrel and T. C. Koopmans in the 1950s. In economics, efficiency refers to the optimal use of resources to avoid waste. However, in order to use this concept correctly, it is necessary to note that efficiency has two important objective distinctions: technical and allocative. The first refers to the managerial capacity of firms to obtain maximum product from a set of productive inputs. The second measure seeks to verify the firm's ability to allocate resources in optimal proportions given its relative prices (CHARNES et al., 1994).

There are several studies in the Brazilian sanitation sector that use Data Envelopment Analysis (DEA) which show the importance of achieving efficiency in the provided services. Barbosa, Tomaz and Azevedo (2019) sought to relate the efficiency of sanitation services in the municipalities of Minas Gerais with socioeconomic variables and, despite finding that only $25 \%$ of the cities surveyed are fully efficient in service provision, their results did not reveal the presence of correlation between the sector and socioeconomic indicators, with the exception of GDP per capita. According to the authors, the data suggest that even though the majority of municipalities which suffer from some kind of inefficiencies, these inefficiencies were not able to impact negatively or positively in a relevant way in the living conditions of the population.

In a larger study, Bittelbrunn et al. (2016) showed that inefficiency in the sanitation sector has been reduced in Brazilian states, especially with regards to the provided services. However, although efficiency levels have increased, this progress has been very slow. In their work, the authors used as variables the amount of active water and sewage connections as well as the extension of the network to assess the services performance. The results showed that Paraná, Tocantins and Minas Gerais were the only states to achieve maximum efficiency in the services provided during the study period (2012-2016).

Da Hora et al. (2015) evaluated the efficiency of Rio de Janeiro's municipalities with the same variables used by Bittelbrunn et al. (2016) and it was identified that several municipalities had inefficiencies in sanitation services. Beyond that, it was observed that the urban population predominantly had better access to water and sewage services. However, it was not possible to indicate the existence of a direct relationship between the service inefficiency and diseases linked to inadequate sanitation. Even so, it is prudent to expect that if there is an improvement in the provision of these services, there will be a reduction in hospitalizations caused by parasitic-infectious diseases. 
Scaratti, Michelon and Scaratti (2013) evaluated the management of municipal water supply and sewage services efficiency with an expanded view on the topic. The authors listed the sector's efficiency indicators from the customers perspective (final consumer of services), the market (supply and demand for water and sewage), product and service compliance (water quality and sewage treatment level) and business performance (total expenditure on exploration, personnel, repairs and revenue). The main result was the identification of inefficiencies associated with economic and financial management, conformity of products and services and ability to serve the market. This occurs, according to the authors, due to the political-governmental neglect, in maintaining natural monopolies and also due to low investments in this sector.

The reality presented in the aforementioned works is evident, that is, there is little efficiency in the sanitation sector and its consequences are perceived both in the public sphere, with regards to service deficit problems, and in society, where several preventable diseases cause health problems to the population that slowly gets sick and becomes unproductive. However, for this second aspect, the evidence is still scarce for the Brazilian case.

Valdevino et al. (2010) analyzed how the efficiency of sanitation services in the municipalities of Tocantins could enhance the fight against endemic diseases (trachoma, schistosomiasis, leptospirosis and diarrheal infections) related to this theme. The model applied by the authors was composed of variables that directly expressed the service and the volume of water offered as well as its quality. The results showed a big difference in the observed cases of endemic diseases between efficient and inefficient municipalities. However, it is important to point out that indicators related to sanitary sewage were not accounted for, given that the municipalities under analysis had practically no sewage system installed, which in some way limits the results found.

\section{Methodology}

\subsection{Type of research and methodological procedures}

Our research is based on a quantitative cross sectional model that seeks to analyze the cause and effect relationship between previously selected variables. The model will be built in two stages. In the first stage, the DEA technique will be used to measure the (relative) technical efficiency of Brazilian municipalities in terms of water and sewage services.

DEA aims to measure the relative efficiency of a given set of decision-making units (DMU) which have characteristics in common. In the present study, each municipality will be considered an independent DMU. The DEA is an essentially non-parametric method, that is, there is no assumption on the functional form that the data can take. What happens is that an efficiency frontier is estimated based on each DMU's own information, when municipalities are positioned above the frontier are considered efficient and the rest is considered inefficient. The degree of inefficiency is given by the distance that a municipality has in relation to the DMU's which posses similar characteristics among themselves, but are located above the estimated frontier (MEDEIROS and MARCOLINO, 2018). 
According to Cesconetto, Lapa and Calvo (2008), DEA has two classic models as a way of approaching efficiency: CCR and BCC. The first one assumes that the DMU's under analysis have constant returns to scale (CRS) while the second adopts the possibility of the existence of variables returns to scale (VRS), which may cause an increase or decrease in the evaluated product. For the present work, the VRS model was adopted, as it is common for sanitation services to have economies of scale that are more than proportional.

Regarding the type of modeling adopted, the DEA can be oriented towards inputs, in which the objective is to minimize the use of resources proportionally, keeping the quantity of products from the operation fixed. There is also an orientation towards the product (outputs), where the product will be maximized, keeping the quantity of inputs used by the DMU's fixed (CHARNES, et al., 1994). In view of the fact that it is unlikely that investment in a key-sectors such as sanitation will be cut, in the present study, DEA with product orientation was adopted.

In this sense, the DEA-VRS model will be built to maximize the outputs and can be presented through the linear programming problem (CHARNES et al., 1994):

$$
\begin{aligned}
& \max _{\phi, \lambda} \phi+\varepsilon \cdot 1 s^{+}+\varepsilon \cdot 1 s^{-} \\
& \text {subject to } \varphi y_{i}-Y \lambda=0 \\
& -x_{i}+X \lambda=0 \\
& 1 \lambda=0 \\
& -\lambda \leq 0
\end{aligned}
$$

The term $\varphi$ is a scalar measure that can take values $\geq 1$ and indicates the technical efficiency of the DMU under analysis. If $\varphi=1$ the DMU will be considered efficient in relation to others, otherwise it will be inefficient; $y_{i}$ is a vector $m \times 1$ of the quantities of outputs of the i-th DMU; $Y$ is the matrix $(m x j)$ of outputs of the DMU's; $x_{i}$ represents a vector of $k \times 1$ inputs from each DMU included in $Y$; the term $\mathrm{X}$ is the matrix $(\mathrm{n} \times \mathrm{j})$ of inputs; $\lambda$ is a vector $(j \times 1)$ of weights preceded by a vector with $\mathrm{n} \times 1$ of ones. The terms $1 s^{-}$and $1 s^{+}$are the output slack and the excess input used in production. If the DMU is evaluated as efficient, these terms must have a value of zero. The term $\varepsilon$ is an infinitesimal constant and, for calculation purposes, it is not considered when creating the efficiency frontier. The presence of this constant is to ensure that the technique prioritizes maximization at the moment of the computational formulation of the problem.

After the classification of efficient and non-efficient municipalities, the second methodological stage was constructed with a multiple linear regression model where, together with the efficiency variable, indicators that represent the conditions of the sanitation services were inserted to assess the impact of these variables on the average cost of hospitalization in the Brazilian municipalities surveyed. 
According to Wooldrigde (2010), a multiple linear regression model is a model that has more than one explanatory variable (independent) related to a variable to be explained (dependent). This model can be represented as shown in equation 2:

$$
Y=\beta_{0}+\beta_{1} X_{1}+\beta_{2} X_{2}+\ldots .+\beta_{j} X_{j}+\mu
$$

Where $Y$ represents the dependent variable, $X_{j}, j=0,1, \ldots, k$ indicate all the explanatory variables or regressors included in the model, $\beta_{j}, j=0,1, \ldots, k$ are the estimated coefficients by the regression and they represent the expected variations in $Y$ when

there is a variation in any $X_{j}$, keeping the other variables unchanged and $\mu$ represents a random error term (residue) which carries all the variability which affects $Y$, but that cannot be explained by the regressors of the model.

Regression estimators can be calculated in several ways. One of the ways of finding the coefficients is by the method of ordinary least squares (OLS). According to Wooldrigde (2010), the "beta" coefficients in this method are estimated in such a way that the sum of the squares of the residuals will be minimized.

\subsection{Sampling and the set of studied variables}

Regarding the sample, the 100 largest Brazilian municipalities in terms of population were chosen to compose the study. The choice for these cities is due to the fact that authors such as Siqueira et al. (2017), Uhr, Schemel and Uhr (2016) and organizations like the WHO emphasize that it is in large metropolitan regions where the lack of basic sanitation has the greatest impact on people's health conditions, because of the greater population density of these areas.

The set of variables chosen to compose the DEA was considered thinking about what information would be relevant to measure the delivery of these services to the population. Authors such as Valdevino et al. (2010) and Da Hora and Costa (2015) used a mix of operational and financial variables to build the technical efficient frontier. Based on this idea, the present work proposed to use as inputs the exploration expenditures and the total number of employees allocated to sanitation services. As outputs, the variable number of active water connections, the number of active sewage connections, the extension of the water network per connection and the extension of the sewer network per connection were chosen. Box 1 presents a summary of the variables to be used for the DEA modeling. 
Box 1. Set of variables for the DEA application.

\begin{tabular}{|c|c|l|}
\hline $\begin{array}{c}\text { Type of } \\
\text { variable }\end{array}$ & Variable & \multicolumn{1}{c|}{ Definition } \\
\hline \multirow{4}{*}{ Inputs } & $\begin{array}{c}\text { Exploitation expenditures } \\
\text { (FN015) }\end{array}$ & $\begin{array}{l}\text { Anual value of expenditures for the exploitation of } \\
\text { services, covering personnel expenditures, chemical } \\
\text { product, eletrical energy, third-party services, fiscal or tax- } \\
\text { related expenditures. }\end{array}$ \\
\cline { 2 - 4 } & $\begin{array}{c}\text { Total quantity of } \\
\text { employees allocated } \\
\text { (FN026) }\end{array}$ & $\begin{array}{l}\text { Total quantity of employees, be it the service provider } \\
\text { employee, manager or any other permanent position } \\
\text { related to the service provider. }\end{array}$ \\
\hline \multirow{4}{*}{ Outputs } & $\begin{array}{c}\text { Quantity of active water } \\
\text { links (AG002) }\end{array}$ & $\begin{array}{l}\text { Total quantity of active water links to the public water } \\
\text { network system, provided or not by a hydrometer, which } \\
\text { were fully functional on the last day of the reference year. }\end{array}$ \\
\cline { 2 - 4 } & $\begin{array}{c}\text { links (ES002) } \\
\text { Extension of the water } \\
\text { network per link (IN020) }\end{array}$ & $\begin{array}{l}\text { Total quantity of active sewer links to the public sewage } \\
\text { network system, which were fully function on the last day } \\
\text { of the reference year. }\end{array}$ \\
\cline { 2 - 4 } & $\begin{array}{l}\text { Relation between the extension in length of the water } \\
\text { network and the total quantity of water links to the } \\
\text { network }\end{array}$ \\
\hline $\begin{array}{c}\text { Extenson of the sewage } \\
\text { network per link (IN021) }\end{array}$ & $\begin{array}{l}\text { Relation between the extension in length of the sewage } \\
\text { network and the total quantity of sewer link to the } \\
\text { network. }\end{array}$ \\
\hline
\end{tabular}

Source: Authors.

Regarding the multiple linear regression model, it was given preference to the most studied variables in other works, including, in addition, other variables that are still under explored within this theme. In this sense, variables which capture the level of investment in sanitation as well as the situation of treated sewage were added to the study due to its remarkable importance in the literature, as highlighted by Uhr, Schemel and Uhr (2016), Begum, Ahmed and Sen (2011) and ITB (2013). Thus, investment over tax collection of municipalities and a treated sewage index in relation to water consumed were the variables chosen to measure the level of investment in sanitation and the situation of sanitation, respectively.

Additionally, other water and sewage variables were explored so that they could contribute to explain the behavior of hospitalization costs for the chosen municipalities. In order to prove the importance of universal access to treated water and sanitation, other variables were included in the study which sought to measure the access or improvement to these services. The variables chosen for this purpose were extension of the sewage network per connection, incidence of non-standard total coliform analyzes, total water service index and extension of the water network per connection. Box 2 presents a description of all the variables as well as their sources. 
Box 2. Multiple Linear Regression variables.

\begin{tabular}{|c|c|c|}
\hline Variable & Description & Unity \\
\hline $\begin{array}{l}\text { Average Cost Per } \\
\text { Admission (ACA). }\end{array}$ & $\begin{array}{l}\text { Average value spent per registered hospital admission } \\
\text { related to intestinal infectious diseases, sanitation related } \\
\text { protozoa, arborvirosis (dengue and malaria), helminthiasis } \\
\text { (worms such as cysticercosis and amoebiasis) and skin } \\
\text { diseases linked to sanitation (trachoma and other } \\
\text { infectious diseases). }\end{array}$ & $\mathrm{R} \$ / \mathrm{admission}$ \\
\hline $\begin{array}{l}\text { Efficient Sanitation } \\
\text { Services (ESS) }\end{array}$ & $\begin{array}{l}\text { Dichotomous variable (dummy) assuming a value of } 1 \\
\text { for municipalities considered efficient and } 0 \text { for those } \\
\text { classified as inefficient by the DEA. }\end{array}$ & - \\
\hline $\begin{array}{l}\text { Extension of the } \\
\text { water network per } \\
\text { link (IN020). }\end{array}$ & $\begin{array}{l}\text { Ratio between the extension of the water network system } \\
\text { and the number of total water links. }\end{array}$ & meters/links \\
\hline $\begin{array}{l}\text { Index of treated } \\
\text { sewer to the water } \\
\text { consumed (IN046). }\end{array}$ & $\begin{array}{l}\text { Ratio between the total amount of water consumed } \\
\text { and treated and the volume of treated sewage in the } \\
\text { municipalities. }\end{array}$ & percentage \\
\hline $\begin{array}{l}\text { Incidence of fecal } \\
\text { coliforms above } \\
\text { laboratory analysis } \\
\text { standards (IN084). } \\
\end{array}$ & $\begin{array}{l}\text { Ratio between the number of total samples analyzed and } \\
\text { the number of results of non-standard samples. }\end{array}$ & percentage \\
\hline $\begin{array}{l}\text { Index of water supply } \\
\text { services (IN055). }\end{array}$ & $\begin{array}{l}\text { Ratio between the total population served with } \\
\text { water supply and the total population residing in the } \\
\text { municipality }\end{array}$ & percentage. \\
\hline $\begin{array}{l}\text { Extension of the } \\
\text { sewer network system } \\
\text { per link (IN021). }\end{array}$ & $\begin{array}{l}\text { Ratio between the extent of the sewage network system } \\
\text { and the number of total sewage links. }\end{array}$ & meters/links \\
\hline $\begin{array}{l}\text { Investment over tariff } \\
\text { revenues (ITR). }\end{array}$ & $\begin{array}{l}\text { Ratio between the total invested by the state or private } \\
\text { company in water supply /sewage and the total collected } \\
\text { with water and sewage operational revenues. }\end{array}$ & percentage \\
\hline
\end{tabular}

Fonte: Authors.

All the variables regarding sanitation were collected on the National Sanitation Information System (SNIS) while the ACA variable was extracted from the DATASUS database. The reference year for the data is 2018, as it is the most recent period for which there is data from all municipalities under analysis. Thus, the specification of the linear regression model is described in equation 1 :

$$
A C A=\beta_{0}+\beta_{1} E S S+\beta_{2} I N 020+\beta_{3} I N 046+\beta_{4} I N 084+\beta_{5} I N 055+\beta_{6} I N 021+\beta_{7} I T R+u_{i}
$$

Regarding the expected signs for each variable, it is assumed that all angular coefficients (except for $\beta_{4}$, an increase in this variable would mean a greater number of samples outside the appropriate standard) to be estimated must show negative values, as the previous literature is emphatic in emphasizing that better sanitation indicators, as well as greater investments, cause positive results in reducing hospitalizations, suggesting a drop 
in the average cost. For the ESS variable, inefficiency is expected to have a negative impact on the average cost of hospitalizations. However, since we do not know which policy and which sanitation area is the most adequate to find better results, it is considered that the magnitude of the angular regression coefficients can contribute to better direct us to the right answer.

\section{Analysis of the results}

Initially, some of the main descriptive statistics of the variables that make up the linear regression model were verified in order to explore their characteristics in terms of central position and dispersion for the detection of sample errors and discrepant data. Although many variables are measured on limited scales (percentages), there was great variability in data dispersion. Table 1 presents the results of some descriptive statistics.

Table 1. Principais estatísticas descritivas do estudo.

\begin{tabular}{c|c|c|c|c}
\hline Variables & Average & $\begin{array}{c}\text { Standard } \\
\text { Deviation }\end{array}$ & Mínimum & Maximum \\
\hline ACA & 2080.072 & 1435.027 & 422.23 & 7464.02 \\
\hline ITR & 32.2353 & 58.0242 & 0.0 & 566.22 \\
\hline IN020 & 10.3744 & 3.2451 & 4.0 & 17.40 \\
\hline IN046 & 51.19 & 30.8984 & 0.0 & 100.00 \\
\hline IN084 & 27844 & 7.6704 & 0.0 & 69.23 \\
\hline IN055 & 91.5573 & 16.3609 & 0.0 & 100.00 \\
\hline IN021 & 9.5555 & 3.7014 & 3.53 & 24.52 \\
\hline
\end{tabular}

Source: Survey data.

$\mathrm{N}=100$ observations

From the results presented, it is possible to see that, on average, the average hospitalization costs (ACA) for diseases linked to the lack of adequate sanitation was $R \$$ 2.080,07 for the surveyed municipalities. Cities such as Betim-MG, Belo Horizonte-MG and Jaboatão dos Guararapes-PE were the ones that registered the highest costs, confirming what authors such as Fonseca et al. (2017) and Van Minh and Hung (2011) commented on the higher incidence of expenses and hospitalizations of these types of morbidities in metropolitan regions and their peripheries.

Another result that is important to highlight is in relation to the variable investment over tariff revenues (ITR). Table 1 indicated that, on average, municipalities invested $32.23 \%$ of their resvenues from operating water and sewage services. Cities like São Gonçalo-RJ, Pelotas-RS and Várzea Grande-MT had the worst results, the latter being the only one in the sample with investment values equal to $0 \%$. Despite the high deviation in the data, this results reveal that there is still a lack of investment in this sector, which demonstrates the importance of PLANSAB as a guiding mechanism, for in this plan, an investments of about $45 \%$ of tariff revenues had to be met as a goal for the year of 2018 . The descriptive results for the other study variables are analogous to the previous variables. 
Box 3 shows the municipalities efficiency levels according to the DEA technique by using the BCC-VRS model with a product orientation. It was found that only 14 cities managed to achieve maximum efficiency in the provision of services. However, although these cities represent only $20 \%$ of the surveyed sample, on average, municipalities under study obtained an efficiency percentage of $81.32 \%$, which can be considered a high performance

Box 3. Efficiency score of municipalities in sanitation services.

\begin{tabular}{|c|c|c|c|c|c|}
\hline Municípality & Efficienty (\%) & Municípality & Efficienty (\%) & Municípality & Efficienty (\%) \\
\hline Ananindeua & 100.00 & $\begin{array}{l}\text { Governador } \\
\text { Valadares }\end{array}$ & 57.44 & Porto Velho & 84.75 \\
\hline Anápolis & 90.50 & Gravataí & 65.84 & Praia Grande & 69.22 \\
\hline $\begin{array}{c}\text { Aparecida de } \\
\text { Goiânia }\end{array}$ & 100.00 & Guarujá & 59.36 & Recife & 71.42 \\
\hline Aracaju & 52.68 & Guarulhos & 100.00 & $\begin{array}{l}\text { Ribeirão das } \\
\text { Neves }\end{array}$ & 96.43 \\
\hline Bauru & 87.79 & Itaquaquecetuba & 81.27 & Ribeirão Preto & 73.25 \\
\hline Belém & 71.60 & $\begin{array}{c}\text { Jaboatão dos } \\
\text { Guararapes }\end{array}$ & 88.88 & Rio Branco & 100.00 \\
\hline Belford Roxo & 79.68 & João Pessoa & 47.67 & Rio de Janeiro & 87.62 \\
\hline Belo Horizonte & 94.74 & Joinville & 83.85 & Salvador & 66.39 \\
\hline Betim & 90.50 & Juiz de Fora & 78.92 & Santa Maria & 67.77 \\
\hline Blumenau & 92.28 & Jundiaí & 95.34 & Santarém & 100.00 \\
\hline Boa Vista & 84.89 & Limeira & 80.43 & Santo André & 72.74 \\
\hline Brasília & 82.05 & Londrina & 72.03 & Santos & 100.00 \\
\hline Camaçari & 71.09 & Macapá & 88.04 & $\begin{array}{c}\text { Sáo Bernardo } \\
\text { do Campo }\end{array}$ & 75.97 \\
\hline $\begin{array}{l}\text { Campina } \\
\text { Grande }\end{array}$ & 62.15 & Maceió & 49.52 & São Gonçalo & 65.18 \\
\hline Campinas & 80.27 & Manaus & 100.00 & $\begin{array}{c}\text { São Joáo de } \\
\text { Meriti }\end{array}$ & 62.75 \\
\hline Campo Grande & 100.00 & Maringá & 89.91 & $\begin{array}{l}\text { São José do } \\
\text { Rio Preto }\end{array}$ & 90.25 \\
\hline $\begin{array}{c}\text { Campos dos } \\
\text { Goytacazes }\end{array}$ & 64.36 & Mauá & 88.86 & $\begin{array}{l}\text { Sáo José dos } \\
\text { Campos }\end{array}$ & 71.05 \\
\hline Canoas & 59.20 & Mogi das Cruzes & 60.04 & $\begin{array}{l}\text { São José dos } \\
\text { Pinhais }\end{array}$ & 100.00 \\
\hline Carapicuíba & 72.14 & Montes Claros & 98.84 & São Luís & 52.04 \\
\hline Cariacica & 84.01 & Mossoró & 54.27 & São Paulo & 100.00 \\
\hline Caruaru & 100.00 & Natal & 70.62 & São Vicente & 63.49 \\
\hline Cascavel & 100.00 & Niterói & 69.87 & Serra & 91.56 \\
\hline Caucaia & 100.00 & Nova Iguaçu & 50.52 & Sorocaba & 82.05 \\
\hline Caxias do Sul & 86.73 & Olinda & 100.00 & Suzano & 80.84 \\
\hline Contagem & 86.84 & Osasco & 84.20 & $\begin{array}{l}\text { Taboão da } \\
\text { Serra }\end{array}$ & 84.55 \\
\hline Cuiabá & 81.04 & Palmas & 100.00 & Taubaté & 86.03 \\
\hline Curitiba & 90.61 & Paulista & 100.00 & Teresina & 66.91 \\
\hline
\end{tabular}




\begin{tabular}{|c|c|c|c|c|c|}
\hline Municípality & Efficienty (\%) & Municípality & Efficienty (\%) & Municípality & Efficienty (\%) \\
\hline Diadema & 84.33 & Pelotas & 56.53 & Uberaba & 82.51 \\
\hline $\begin{array}{c}\text { Duque de } \\
\text { Caxias }\end{array}$ & 82.88 & Petrolina & 100.00 & Uberlândia & 100.00 \\
\hline $\begin{array}{c}\text { Feira de } \\
\text { Santana }\end{array}$ & 86.53 & Petrópolis & 67.88 & Várzea Grande & 100.00 \\
\hline Florianópolis & 86.15 & Piracicaba & 70.52 & Vila Velha & 78.01 \\
\hline Fortaleza & 100.00 & Ponta Grossa & 88.02 & Vitória & 85.59 \\
\hline Franca & 77.80 & Porto Alegre & 79.44 & $\begin{array}{c}\text { Vitória da } \\
\text { Conquista }\end{array}$ & 86.05 \\
\hline Goiânia & 77.58 & & & & \\
\hline
\end{tabular}

Source: Survey data.

The results obtained by the efficiency analysis are, for the most part, contrary to what other works had advocated. In a pessimistic scenario, authors such as Siqueira et al. (2016), Barbosa, Tomaz and Azevedo (2019) identified that sanitation services had, on average, an efficiency between $25 \%$ and $30 \%$. On the other hand, the best panorama had been identified by Scaratti, Michelon and Scaratti (2013) and Bittelbrunn et al. (2016) where the average efficiency of the municipalities reached $75 \%$ and $81 \%$, respectively.

The divergences found in the efficiency levels can be explained by the characteristics of the samples. In the studies which have found the lowest efficiency scores, the analysis had focused exclusively on a single Brazilian state. The studies where the results for efficiency were higher covered all Brazilian regions and, therefore, approached the sample of this study with greater reliability.

However, the direct comparison of these efficiency scores and sanitation indicators with the studied literature becomes very complex since these variables are disaggregated and there are no parameters that which could set a given value to be adequate. Therefore, the regression analysis was performed to verify the impact of each of these disaggregated indicators and the efficiency in the IMC of the municipalities that make up the sample. Table 2 presents the first results for the estimated model.

Table 2. Variance Analysis for the Estimate Model.

\begin{tabular}{c|c|c|c|c|c}
\hline & $\begin{array}{c}\text { Sum of } \\
\text { Squares }\end{array}$ & $\begin{array}{c}\text { Degrees of } \\
\text { Freedom }\end{array}$ & $\begin{array}{c}\text { Mean } \\
\text { Squared }\end{array}$ & F-statistic & p-value \\
\hline Regression & 18027342.90 & 7 & 2575334.70 & & \multirow{2}{*}{2.72} \\
\cline { 1 - 4 } Resíduals & 74563340.30 & 79 & 943839.75 & 0.0247 \\
\cline { 1 - 4 } Total & 92590683.20 & 86 & 3519174.45 & & 0.1335 \\
\hline
\end{tabular}

Source: Survey data. 
Table 2 presents the results of the analysis of variance of the model after adjusting the observations. In all, 14 cities $^{3}$ were eliminated, which presented very different values from the rest of the data distribution, three of which (Ananindeua, Olinda and Santarém) were considered efficient by the DEA methodology. Thus, table 2 shows that the proposed model has global significance, that is, the set of variables chosen contributes to explain the variability in the average cost of hospitalization of the municipalities (ACA) in the sample.

Knowing that the set of variables can globally explain the costs of hospitalizations linked to inadequate sanitation, Table 3 shows which of these variables had significant coefficients and their impact on the return of interest.

Table 3. Estimated Coefficients of the Model.

\begin{tabular}{|c|c|c|c|c|}
\hline Variable & Coefficient & t-statistic & p-value & VIF \\
\hline ITR & $\begin{array}{c}-40.3054 \\
(6.6048) \\
\end{array}$ & -6.10 & 0.000 & 1.64 \\
\hline IN020 & $\begin{array}{c}-50.0663 \\
(7.2776) \\
\end{array}$ & -6.87 & 0.000 & 2.19 \\
\hline IN046 & $\begin{array}{l}0.37515 \\
(3.5645) \\
\end{array}$ & 0.11 & 0.916 & 1.31 \\
\hline IN084 & $\begin{array}{c}7.2396 \\
(3.3214)\end{array}$ & 2.17 & 0.033 & 1.45 \\
\hline IN055 & $\begin{array}{c}5.9782 \\
(18.6947) \\
\end{array}$ & 0.32 & 0.750 & 1.82 \\
\hline IN021 & $\begin{array}{c}35.8826 \\
(42.0937) \\
\end{array}$ & 0.85 & 0.397 & 2.10 \\
\hline ESS & $\begin{array}{l}-275.5483 \\
(25.2019) \\
\end{array}$ & -10.93 & 0.000 & 1.17 \\
\hline Intercept & $\begin{array}{c}410.5316 \\
(1902.832) \\
\end{array}$ & 0.22 & 0.830 & - \\
\hline
\end{tabular}

Source: Survey data

Note: Dependent variable: ACA

The results found in table 3 allow us to say that the coefficients for the investment over tariff revenues (ITR), water network extension per connection (IN020), incidence of fecal coliforms above laboratory analysis standards (IN084) and the dummy for the level of efficiency (ESS) were significant. The reason that the other variables were not significant may be due to the fact that such indicators are not capable of capturing the effect on the ACA in a disaggregated manner, making only operational indicators to measure service activities. Therefore, the possible effects of these indicators will only be perceived, from a statistical point of view, if they are combined in other more aggregated indicators.

3 Ananindeua, Belém, Belo Horizonte, Blumenau, Boa Vista, Contagem, Cuiabá, Diadema, Jaboatão dos Guararapes, Macapá, Olinda, Ribeirão Preto, Uberaba e Santarém. 
For the variables that were statistically significant, the results obtained in Table 3 are in conformity with the expected signal, that is, they are capable of reducing the average cost per hospitalization in the sampled municipalities. It is clear that for the variable IN084 the result of its coefficient must be positive, since an increase in this indicator means a decrease in the quality of services provided. Then a reduction in value of this variable would tend to reduce hospitalization costs. Thus, as it is well demonstrated by authors such as Siqueira et al. (2017), Uhr, Schemel and Uhr (2016) and Begum, Ahmed and Sen (2011) investments in sanitation and the consequent improvement in some indicator of this service can contribute to the elimination of unnecessary hospitalizations expenses related to these diseases.

The results have also proved the importance of achieving efficiency in sanitation services. According to the data in table 3, the municipality that presents such performance reduces, on average, the costs of hospitalizations by $\mathrm{R} \$ 275.54$. Thus, it is possible to conclude that the efficiency in sanitation has a great importance in reducing the costs of hospitalizations in the largest Brazilian cities, because with water and sewage services, several diseases transmitted by these means are halted, impacting positively to the betterment of money expenditures, as mention by Valdevino et al. (2010). However, it is important to note that the presence of efficiency does not mean the absence of a service deficit in sanitation, since the performance measure was calculated based on the technical management of resources, and the number of people who still do not receive these services is not computed.

In the present study, the investment in the sanitation area had its effect captured by the ITR variable, which showed that for each 1 p.p. increase in investments over tariff revenues, on average, the cost of hospitalization linked to diseases related to inadequate sanitation falls by about $\mathrm{R} \$ 40.30$. As an indicator of improvement in adequate sanitation access, the variable IN020 showed that for each unit increase in connections per meter of network extension, on average, the variable ACA response is to reduce hospitalization costs by $\mathrm{R} \$ 50.06$. On the other hand, as an indicator of a drop in the quality of services provided in sanitation, the variable IN084 showed that each additional 1 p.p. in inadequate samples, on average, the average cost of hospitalizations related to diseases related to sanitation can increase up to $\mathrm{R} \$ 7.23$.

In view of these results, one can perceive the importance of full coverage in basic sanitation in the Brazilian scenario, considering that the simple fact that having a new piped water connection can contribute significantly to the health of the population and the financial health of the municipalities. This shows that investments related to these services should be directed primarily towards access to treated water for the population, as authors such like Van Minh and Hung (2011) had already detected the importance of having drinking water for the population which lives mainly in peripheral metropolitan regions, as more than $70 \%$ of all diseases linked to poor sanitation are contracted via contaminated water.

In addition, the results obtained can corroborate to the evidence raised by several surveys carried out by the Instituto Brasil, that is, resources destined to the investment of sanitary infrastructure such as the expansion of the piped water network and the sewage collection network sytem as well as the larger quality control in the collection and treatment 
plants can bring benefits that are more than proportional from a financial point of view. However, as noted by Rocha, Rossoni and Faria (2018), investment in this area must be accompanied by substantial improvements in the population's health statistics, since the inefficiency in this type of expenditure can contribute to an increase in sanitation costs.

Finally, with respect to the results obtained in table 3, the last column presents the values for the Variance Inflation Factor (VIF) which indicates whether the explanatory variables of the model have problematic correlations, which could overestimate the explanatory effects of the model due the existence of high multicollinearity phenomenon. According to the literature (GUJARATI, 2011), VIF values that do not indicate problems should be between 1 and 5, with some tolerance up to 10, depending on the type of study. In this sense, it is possible to verify that in the estimated model the problem of multicollinearity can be discarded. However, before concluding that the model has a good quality in the fit, it is necessary to analyze the residual terms of the model for homoscedasticity, normal distribution and autocorrelation. Table 4 presents the results for the developed tests.

Table 4. Analysis of the Residuals of the Model.

\begin{tabular}{c|c|c|c|c}
\hline \multicolumn{2}{c|}{ Shapiro-Wilk Test } & Durbin-Watson Test & \multicolumn{2}{c}{ Breusch-Pagan Test } \\
\hline W statistic & p-valor & Dw-statistic & Statistic & p-value \\
\hline 0.9797 & 0.2361 & 2.2954 & 65.22 & 0.2243 \\
\hline
\end{tabular}

Source: Survey data.

The table results show the tests for normality in the distribution of errors, the absence of first-order autocorrelation and error variance homoscedasticity, respectively. Regarding normality, it is evidenced by the Shapiro-Wilk test that the error terms are normally distributed, since their null hypothesis was not rejected. For first-order autocorrelation of errors, the Durbin-Watson statistic was used. From the result observed in table 4, a rule of thumb can be adopted regarding the use of the test. According to Gujarati (2011), from values close to 2 , the dw statistic indicates that there is no autocorrelation of errors and it is said that there is no first-order linear association with the regression residues; for values close to 0 there is a positive correlation, while values close to 4 show a negative correlation. Thus, for the estimated model, it can be concluded that no autocorrelation was detected.

Concluding the residue analysis, it is necessary to verify the behavior of the error variance. Such a procedure is essential for the accuracy of the model estimators. If there is any systematic behavior in the variance of the residuals, the coefficients estimated by the model will be inefficient, losing the minimum variance property. In this sense, the BreuschPagan test was used to assess the presence of heteroscedasticity. According to table 4, the hypothesis of heteroscedasticity was rejected, suggesting that the error variance remains homoscedastic in all units of cross section.

\section{Final comments}

The present work had as its objective to explain how the efficiency and the investment in basic sanitation as well as its indicators impacts on the average cost of hospitalizations due 
to diseases related to inadequate levels of sanitation and performance of the aforementioned variables and indicators in the largest brazilian municipalities. The results thus obtained showed that only $20 \%$ of the municipalities accounted in the study were technically efficient in water and sewage services.

As to the model, even though a low determination coefficient was found, the included variables in the regression showed themselves to be important to explain to some degree the cost of hospital stays. From the proposed variables, investment over tax collection, the extension the water network per connection, the incidence of fecal coliforms above laboratory analysis standards, and the presence of efficient provided services were the ones which showed statistical significance, proving the idea that there exists a negative relationship between sanitation improvements and hospital admissions.

Regarding the variables which were considered to be statistically significant in our study, the estimated coefficients have fulfilled the requirements such that they could be considered valid, that is, they are the best linear unbiased estimators, guaranteeing that the model has a correct specification.

Beyond that, the coefficients that were found showed that full coverage of sanitation services is essential. Piped water, the variable that better captured the access to those services (IN020), has shown itself to be highly relevant to the model. As such, the results point out as to where public policies should direct its resources, that is, the sanitation infrastructure must be amplified and improved, having as its main pillar an increase in the number of links of piped water per meter of installed sewage network system.

Following this logic, a greater access to piped water is capable of eliminating to a large extent diseases related to inadequate sanitation, thus making, by consequence, the number of hospital stays due to infection by these diseases to be decreased. This might cause a brutal fall on the average cost per hospital admission for the brazilian municipalities, since every year almost 1 million people are admitted having as its cause inadequate sanitation.

In the face of what was presented in this work, we can conclude that our model contributes to the reduction of informational asymmetry, since it shows in an objective way which parameter must be prioritized such that national sanitation policies, like PLANSAB, don't fail and waste resources that, increasingly, have come to be of paramount importance to the federal union and its municipalites.

Even though our objectives were reached, it is important to highlight that our model has several limitations. The fact that it has few explanatory variables has impacted significantly its predictive power, making it hard for a more detailed analysis on how much the average cost per hospital admissions could have fallen. The absence of a variable which could measure the rural area and its effects on the municipalities could have also underestimated our results. Setting a difference between rural and urban areas on the indicators, we could have better predicted how each region affects the average cost per admission.

For future studies, it is proposed that a larger set of sanitation indicators should be included, such as, for example, solid residuals indicators, which could increase the predictive power of the model, as well as the inclusion of dummy variables to distinguish between some characteristics which could be important, like the percentage of treated water 
in rural and urban areas, the size of the population lacking in these services, and yet if the service provision is made either by public or private institutions.

\section{References}

ARAUJO, W. M. B. Análise dos custos com internaçóes hospitalares com crianças de até um ano de idade no Brasil por Grandes Regióes entre 2006 e 2016. Trabalho de Conclusão de Curso. Universidade Federal do Rio Grande do Norte. 2017.

BARBOSA, A. L.; TOMAZ, D. A.; AZEVEDO, A. A. Análise da eficiência dos serviços de saneamento prestados nos municípios da região metropolitana de Belo Horizonte com a utilização do método Análise Envoltória de Dados. Brazilian Journal of Production Engineering, v. 5, n. 1, p. 101-121, 2019.

BEGUM, S.; AHMED, M.; SEN, B. Do Water and Sanitation Interventions Reduce Childhood Diarrhoea? New Evidence from Bangladesh. Bangladesh Development Studies. v. XXXIV, n. 3, 2011.

BITTLELBRUNN, F; BRINCKMANN, R.; ANDRETT, M. C.; PFITSCHER, E. R. Estudo da eficiência dos gastos com saneamento básico dos estados brasileiros e DF entre 2012 e 2014 por meio de Análise Envoltório de Dados. In: Anais do Congresso Brasileiro de Custos-ABC. 2016.

CHARNES, A.; COOPER W. W.; LEWIN, A. Y.; SEIFORD, L. M. Data envelopment analysis: theory, methodology and applications. Spring: Netherlands. 1994.

CESCONETTO, A.; LAPA, J. S.; CALVO, M. C. M. Avaliação da eficiência produtiva de hospitais do SUS de Santa Catarina, Brasil. Cadernos de Saúde Pública, v. 24, n. 10, 2404-2417. 2008.

DA HORA, A. L.; SHIMODA, E.; DA HORA, H. M.; COSTA, H. G. Análise da eficiência dos serviços de saneamento básico nos municípios do estado do Rio de Janeiro.

Pesquisa Operacional para o Desenvolvimento, v. 7, n. 1, p. 55-81. 2015.

DUFLO, E.; MICHAEL GREENSTONE, RAYMOND GUITERAS, AND THOMAS CLASEN. Toilets Can Work: Short and Medium Run Health Impacts of Addressing Complementarities and Externalities in Water and Sanitation, NBER Working Paper, No. 21521, 2015.

FEWTRELL, L.; PRUSS-USTUN, A.; BOS, R.; GORE, F; BARTRAM, J. Water, sanitation and hygiene: quantifying the health impact at national and local levels in countries with incomplete water supply and sanitation coverage. Environmental Burden of Dieases Series. 2007. 
FONSECA, F. R.; VASCONCELOS, C. H. Análise espacial das Doenças Relacionadas ao Saneamento Ambiental Inadequado no Brasil. Cad. Saúde Colet, v. 19 n. 4, p. 448-453. 2017.

GUJARATI, D. Econometria Básica 5ed. Amgh Editora, 2011.

INSTITUTO TRATA BRASIL. Benefícios econômicos e sociais da expansáo do saneamento no Brasil. 2018. Disponível em: <http:/www.tratabrasil.org.br/estudos/ estudos-itb/beneficios-economicos-e-sociais>. Acesso em: 10/12/19.

MEDEIROS, R. V.; MARCOLINO, V. A. A eficiência dos municípios do Rio de Janeiro no setor de saúde: Uma análise através da DEA e regressão logística. Revista Meta: Avaliaçáo, v. 10, n. 28, p. 183-210, 2018.

ORGANIZAÇÃO MUNDIAL DA SAÚDE (OMS). Agua y saneamiento: evidencias para políticas públicas com enfoque em derechos humanos y resultados en salud pública. Washington: Organizacion Panamericana de La Salud; 2011.

PLANO NACIONAL DE SANEAMENTO BÁSICO (BRASIL). Secretaria Nacional de Saneamento Ambiental. Plano Nacional de Saneamento Básico - PLANSAB Subsídios para a definição do Projeto Estratégico de elaboração do PLANSAB, 2007. Disponível em: Disponível em: <http://www.abm.org.br/PLANSAB.pdf>.

ROCHA, A. C. T.; ROSSONI, H. A. V.; FARIA, M. T. Determinantes envolvidos no perfil de doenças relacionadas às condiçóes sanitárias inadequadas nos munícipios brasileiros: avaliação realizada nas 10 melhores e 10 piores cidades do ranking do saneamento. ForSci IFMG, v. 6, n. 2, p. 2-22, 2018.

SABBIONI, G. Efficiency in the Brazilian sanitation sector. Utilities Policy, v. 16, n. 1, p. 11-20, 2008.

SCARATTI, D.; MICHELON, W.; SCARATTI, G. Avaliação da eficiência da gestão dos serviços municipais de abastecimento de água e esgotamento sanitário utilizando Data Envelopment Analysis. Eng Sanit Ambient, v. 18, n. 4, 2013

SCRIPTORE, J. S.; AZZONI, C. R.. Impactos do Saneamento Básico Sobre a Saúde: Uma Análise Espacial. Associação Nacional dos Centros de Pós-Graduação em Economia, 2018.

SEROA DA MOTTA, R.; MOREIRA, A. Efficiency and regulation in the sanitation sector in Brazil. Utilities Policy, v. 14, n. 3, p. 1185-195, 2006.

SIQUEIRA, M. S.; ROSA, R. S.; BORDIN, R.; NUGEM, R. C. Internaçóes por doenças relacionadas ao saneamento ambiental inadequado na rede pública de saúde da 
regiāo metropolitana de Porto Alegre-RS entre 2010-2014. Epidemol. Serv. Saúde, v. 26, n. 4, p. 795-806. 2017.

TUPPER, H. C.; RESENDE, M. Efficiency and regulation issues in the Brazilian water and sewerage sector: an empirical study. Utilities Policy, v. 12, n. 1, p. 29-40, 2004.

UHR, J. G. Z.; SCHMECHEL, M.; UHR, D. A. P. Relação entre saneamento básico no Brasil e saúde da população sob a ótica das internaçóes hospitalares por doenças de veiculação hídrica. RACEF, v. 7, n. 2, p. 01-16, 2016.

VALDEVINO, A. A.; MEDEIROS, J. C.; NASCIMENTO, A. P.; PESSOA, A. P. Avaliação da eficiência dos serviços de saneamento básico no combate às endemias nos municípios do Estado do Tocantins. Informe GEPEC, v. 14, n. 2, p. 166-181, 2010.

VAN MINH, H.; HUNG, N. V. Economic aspects of sanitation in developing countries. Environmental health insights, v. 5, p. EHI. S8199, 2011.

WOOLDRIDGE, J. M. Introduçáo à econometria: uma abordagem moderna.

Pioneira Thomson Learning, 2006. 